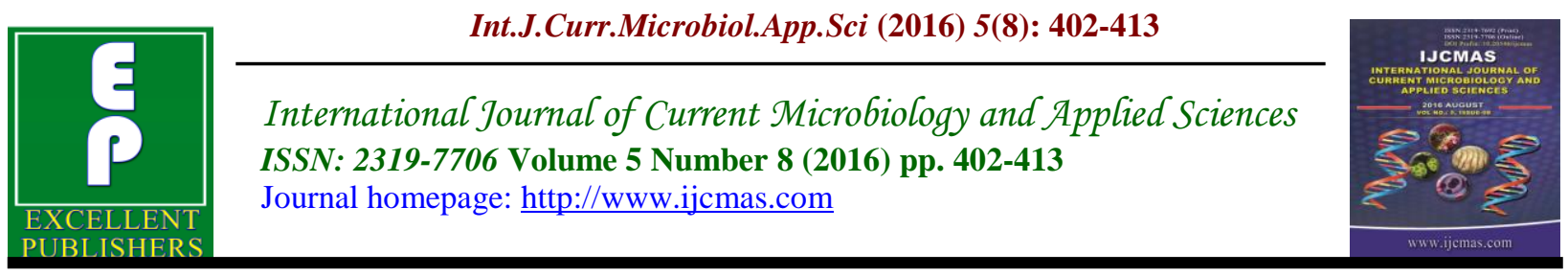

Original Research Article

http://dx.doi.org/10.20546/ijcmas.2016.508.043

\title{
Prevalence and Distribution of Diatoms in the Paddy Fields of Rasipuram Area, Namakkal Dt, Tamilnadu, India
}

\author{
K. Nashima* and A. Palanisamy \\ Muthayammal College of Arts \& science, Rasipuram, Tamilnadu India \\ *Corresponding author
}

Keywords

Diatoms,

Navicula sp.

Nitzchia sp.

Pennales and

Centrales.

\section{Article Info}

Accepted:

17 July 2016

Available Online:

10 August 2016

\section{A B S T R A C T}

Diatoms are a large and diverse group of eukaryotic algae belongs to the members of Bacillariophyceae. Usually microscopic, diatoms are well known to be abundant in paddy fields. They are the largest group of biomass producers on earth; they are one of the predominant contributors to global carbon fixation and $25 \%$ of the total oxygen production on earth. Diatoms are enormously successful organisms as judged by their adaptability, distribution, biomass and relative antiquity. In the present study focused on the prevalence of diatoms from different paddy fields of Rasipuram area, Namakkal District, Tamilnadu, India. Total number of 200 samples were collected from paddy fields of Rasipuram area. 351 isolates of 18 diatom genera was recorded during this study period. Among the four different seasons, it was found that July to August, 2011 recorded the highest number of (190) and the lowest number (87) was recorded during December, 2012 to February, 2013. Among them dominant genera were Navicula sp. (49 isolates) followed by Nitzchia sp. (48 isolates) during July to August, 2011.

\section{Introduction}

Diatoms are a large and diverse group of eukaryotic algae. They are the members of Bacillariophyceae, distributed throughout the world from fresh and brackish water habitats. Usually microscopic, some species of diatoms can reach up to 2 millimeters in length. They are one of the most important food resources in marine and freshwater ecosystems. They are mostly unicellular, although some form chains or simple colonies in the shape of filaments of ribbons and the cells are golden brown because of the presence of high levels of flucoxanthin, a photosynthetic accessory pigment. There are many thousands of taxa with diverse ecological requirements, their siliceous cell wall called the frustules remains are used extensively as environmental indicators in studies of climate change, acidic precipitation and water quality (Stoermer and Smol, 1999).

Several other Xanthophylls are present at lower levels, as well as $\beta$-carotene, chlorophyll a and Chlorophyll $\mathrm{C}$. There are more than 200 genera of living diatoms, and it is estimated that more than 100,000 species exist. Number of recognized diatoms is 10000 - 12000 (Norton et al., 1996). Diatoms are traditionally divided into two 
orders: Centric diatoms (Centrales), which are radially symmetric. Pennate diatoms (pennales) are bilaterally symmetric. Diatoms generally range in size from 2$200 \mu \mathrm{m}$. The main storage compounds of diatom are lipids (TAGS) and a $\beta-1-3-$ Linked carbohydrate known as chrysolaminarin (Sheehan et al., 1998). Diatoms are considered as one of the fundamental players in the physical and biochemical processes that characterized the ecosystem therefore play a significant role in earth's biochemistry (Graham and Wilcox, 2000).

Diatoms have been widely used to reconstruct past changes in $\mathrm{pH}$ (Birks et al., 1990), salinity (Fritz, 1990), nutrients (Fritz et al., 1993) and climatic changes (Dean et al., 1984). Desikachary's contributions to the diatoms of India deserve a special mention (Desikachary, 1959).

Previous studies and taxonomic lists of diatoms for the Chesapeake Bay have focused primarily on the phytoplankton component of the diatom flora (Wolfe et al., 1926; Morse, 1947; Griffith, 1961; Mulford, 1962; Patten et al., 1963; Marshall, 1984, 1986). More recently, examined the distribution patterns of both planktonic and benthic diatoms in the Severn River (a Chesapeake Bay tributary). In a series of papers, Cooper has documented the diatom community structure changes in relation to land use changes over approximately the past 2,000 years (Cooper and Brush, 1991 and 1993). Diatoms are enormously successful organisms as judged by their adaptability, distribution, biomass and relative antiquity. They account for up to $25 \%$ of the total oxygen production on earth. They are the largest group of biomass producers on earth and they are one of the predominant contributors to global carbon fixation (Norton et al., 1996).
A careful examination shows that many of the attached or enclosed forms also occur in a free state; and that there are frequently very slight differences between species. These circumstances, together with the necessity of using the most excellent and powerful lenses, make the study of the diatoms a difficult one. But that study is of considerable importance. For the complete knowledge of these diatoms it would have been desirable to study them in the living state. The present study was aimed at the prevalence of diatoms from different paddy fields of Rasipuram area, Namakkal District, Tamilnadu, India.

\section{Materials and Methods}

\section{Sample collection}

Water and soil samples $(n=200)$ were collected from different paddy fields in and around Rasipuram, Namakkal District, Tamilnadu, India during July, 2011 to August, 2011, December, 2011 to February, 2012, July, 2012 to August, 2012 and December, 2012 to February, 2013 respectively. Table -1 showing the sampling places of the study area. The samples were collected in thoroughly washed and autoclaved polypropylene sample bottles (Tarson, India), and sterile polythene bags and then samples were transported into the laboratory (Bhardwaj and Tiwari, 2010).

\section{Microscopic observation and Identification}

The microscopic observations of diatom isolates were carried out at 40x and 100x magnification using compound microscope (Olympus). The diatom flora was identified based on the taxonomic criteria as described by Cramer, (1984), Jensen, (1985), Krammer and Lange-Bertalot, (1988) and Benson, (1998). 


\section{Results and Discussion}

The present investigation was carried out on prevalence of diatoms from different paddy fields in and around Rasipuram location, Namakkal District. Algal samples ( $=200 /$ each 50 per season) were collected from different paddy fields in and around Rasipuram area, Namakkal District, Tamilnadu during July, 2011 to August, 2011, December, 2011 to February, 2012, July, 2012 to August, 2012 and December, 2012 to February, 2013.

\section{Microscopic observation and identification}

The samples collected were analysed for the prevalence of diatoms. A Total of 190 isolates of 18 diatom genera representing two orders belonging to seven families were recorded (Table-2 and 3) during July to August, 2011. A total of 12 genera belonging to Pennales and 6 genera belonging to centrales. Among them predominant genera were Navicula sp. (49 isolates) followed by Nitzchia sp. (48 isolates) (Table-2).

As many as 159 isolates of 17 diatom genera representing two orders belonging to seven families were recorded (Table-2 and 3) during July to August, 2012. A total of 12 genera belonging to Pennales and 5 genera belonging to centrales. Among them predominant genera were Navicula sp. (49 isolates) followed by Nitzchia sp. (43 isolates).

Statistical analysis revealed that the occurrence of algal isolates does not show any significantly difference. Therefore, the Diatom found in the study area of JulyAugust 2011 and July-August 2012 is not significantly differed.
During December, 2011 to February, 2012 as many as 95 isolates of 12 diatom genera that represent two orders of six families were recorded (Table-2 and 3). A total of 10 genera belonging to Pennales and 2 genera belonging to centrales. Navicula sp. (29 isolates) followed by Nitzchia sp. (20 isolates) had been predominant genera among the 95 isolates of diatom.

87isolates of 08 diatom genera representing two orders belonging to four families were recorded (Table-2 and 3) during December, 2012 to February, 2013. A total of 7 genera belonging to Pennales and 1 genera belonging to centrales were recorded. Navicula sp. (32 isolates) followed by Nitzchia sp. (19 isolates) had been identified as predominant genera.

The diatom found in the study area during December 2011 - February 2012 and December 2012 - February 2013 is not differed significantly.

Prevalence of diatom from different periods was also recorded (Table-2). Among the four different seasons, it was found that July to August, 2011 recorded the highest number of (190) and the lowest number (87) was recorded during December, 2012 to February, 2013. Among them dominant genera were Navicula sp. (49 isolates) followed by Nitzchia sp. (48 isolates) during July to August, 2011.

Diatoms are well known to be abundant in paddy fields (Kikuchi et al., 1975; Taire and Hogestu 1987; Ohtsuka and Fujita, 2001). A large population of algal as well as diatom flora is available from Kolkata, West Bengal. Several authors have reported diatom flora from various regions of India especially from south and west since long back (Venkataraman 1939; Gandhi 1956, 1959, 1967; Nair 1959, 1960; Ramamoorthy 
1965; Gopalakrishnan 1972; Sarode and Kamat 1979; Somashekar 1983, 1984; Bongale 1985; Prasad and Jaitly 1985; Kannan and Vasntha 1992; Garg and Bhaskar 2000). Though most of the diatoms reported this region are marine and estuarine, there are very few reports of freshwater diatoms from west Bengal by Jena et al., 2006 and Bhattacharya et al., 2011.

In the present study, the presence of seven families of diatom viz Naviculaceae, Nitzschiaceae, Acanthaceae, Fragillariaceae, Coscinodiscaceae, Nediaceae, Diadesmidaceae and Stephonodiscaceae with two orders viz pennales and centrales in the paddy fields were recorded. This study closely matches the findings of Hamed, 2008 in different water habitats of near Cairo and Suez town. Among the four different seasons, it was found that July to August, 2011 recorded the highest number of (190) and the lowest number (87) was recorded during December, 2012 to February, 2013. Among them Navicula sp. (49 isolates) and Nitzchia sp. (48 isolates) were predominant during July to August, 2011. Similar observations were found in Fujita and Ohtsuka, 2005: Fujita and Nakahara, (2006) and Bhattacharya et al., (2011). These results suggest that the diatom that are predominant in paddy soil. Therefore domination of species specifies to definite location, time and change year to year. High population density due to high nutrient concentration.

In this study we reported 351 isolates of 18 diatom genera was recorded during this study (Plate 1). Ohtsuka \& Fujita (2001) reported 92 diatom taxa belonging to 28 genera in a Japanese paddy field. Gore and Sanap, (2009) found 8 genera. Low temperature, water and light deficiency, high light intensities, which may act as limiting factors. The rice field ecosystem provides a favourable environment for the growth of algae since there is adequate supply of light, water, heat and nutrients (Vidyavati, 2012). Calonies sp. Gomphonema sp. Cocconeis sp. Diadesmis sp. and Amphipleura sp. were the lowest number. This was correlated with Leelahakriengkrai and Peerapornpisal, 2008

Table.1 List of samples collected from paddy fields in different locations

\begin{tabular}{|c|l|c|c|c|c|}
\hline \multirow{2}{*}{ S.No } & \multirow{2}{*}{$\begin{array}{c}\text { Location of } \\
\text { sample } \\
\text { collected }\end{array}$} & \begin{tabular}{c} 
July- \\
August, \\
\cline { 5 - 6 }
\end{tabular} & $\begin{array}{c}\text { July- } \\
\text { August, } \\
\mathbf{2 0 1 1}\end{array}$ & $\begin{array}{c}\text { December, 2011- } \\
\text { February, 2012 }\end{array}$ & $\begin{array}{c}\text { December, 2012 } \\
\text {-February, 2013 }\end{array}$ \\
\hline 1 & Pudhupatty & $1-10$ & $1-10$ & $1-10$ & $1-10$ \\
\hline 2 & Mettala & $11-20$ & $11-20$ & $11-20$ & $11-20$ \\
\hline 3 & Namagiripet & $21-30$ & $21-30$ & $21-30$ & $21-30$ \\
\hline 4 & Kakkavary & $31-40$ & $31-40$ & $31-40$ & $31-40$ \\
\hline 5 & Rasipuram & $41-50$ & $41-50$ & $41-50$ & $41-50$ \\
\hline
\end{tabular}


Table.2 List of Diatom taxa found in the paddy fields of Rasipuram

\begin{tabular}{|c|c|c|c|c|c|}
\hline $\begin{array}{l}\text { S. } \\
\text { No }\end{array}$ & Bacillariophyceae (Diatoms) & $\begin{array}{c}\text { July- } \\
\text { August, } 2011\end{array}$ & $\begin{array}{c}\text { July- } \\
\text { August, 2012 }\end{array}$ & $\begin{array}{c}\text { December, 2011- } \\
\text { February, 2012 }\end{array}$ & $\begin{array}{c}\text { December, 2012- } \\
\text { February, 2013 }\end{array}$ \\
\hline \multirow[t]{3}{*}{$\mathrm{I}$} & Order : Pennales & & & & \\
\hline & Sub order : Biraphinidae & & & & \\
\hline & Family : Naviculaceae & & & & \\
\hline 1. & Genus : Calonies sp. & 04 & 02 & 02 & 01 \\
\hline \multirow[t]{2}{*}{2.} & Pinnularia $s p$. & 06 & 05 & _- & _- \\
\hline & $\begin{array}{c}\text { Sub Family : } \\
\text { Gomphocymbelloideae }\end{array}$ & & & & \\
\hline \multirow[t]{2}{*}{3.} & Genus:Gomphonema sp. & 02 & 01 & _ & _ \\
\hline & Sub Family: Naviculoideae & & & & \\
\hline 4. & Genus: Gyrosigma sp. & 08 & 06 & 04 & 05 \\
\hline 5. & Navicula sp. & 49 & 47 & 29 & 32 \\
\hline \multirow[t]{3}{*}{6.} & Stauroneis sp. & 05 & 03 & 02 & - \\
\hline & Family : Nitzschiaceae & & & & \\
\hline & Sub Family : Nitzschioideae & & & & \\
\hline \multirow[t]{4}{*}{7.} & Genus :Nitzchia sp. & 48 & 43 & 20 & 19 \\
\hline & Sub Order : Monoraphidineae & & & & \\
\hline & Family :Acanthaceae & & & & \\
\hline & Sub Family : Cocconeoideae & & & & \\
\hline \multirow[t]{2}{*}{8.} & Genus : Cocconeis $s p$. & 02 & 04 & 01 & - \\
\hline & Sub Family : Acanthoideae & & & & \\
\hline \multirow[t]{4}{*}{9.} & Genus : Acanthes $s p$ & 05 & 04 & 02 & 02 \\
\hline & Sub Order : Araphidineae & & & & \\
\hline & Family : Fragillariaceae & & & & \\
\hline & Sub Family : Fragilarioideae & & & & \\
\hline 10. & Genus : Fragillaria $s p$. & 08 & 09 & 06 & 07 \\
\hline 11. & Tabularia sp. & 04 & 03 & 02 & - \\
\hline 12. & Synedra sp. & 18 & 12 & 09 & 11 \\
\hline \multirow[t]{4}{*}{ II } & Order: Centrales & & & & \\
\hline & Sub Order : Discineae & & & & \\
\hline & Family : Coscinodiscaceae & & & & \\
\hline & $\begin{array}{c}\text { Sub Family : } \\
\text { Coscinodiscodeae }\end{array}$ & & & & \\
\hline \multirow[t]{2}{*}{13.} & Genus : Cyclotella $s p$. & 09 & 11 & 05 & 04 \\
\hline & Family : Nediaceae & & & & \\
\hline \multirow[t]{2}{*}{14.} & Genus : Neidium $s p$. & 07 & 04 & 01 & - \\
\hline & Family : Diadesmidaceae & & & & \\
\hline \multirow[t]{2}{*}{15} & Genus :Diadesmis $s p$. & 01 & 02 & - & - \\
\hline & Family : Stephonodiscaceae & & & & \\
\hline 16. & Genus : Stephonodiscus sp. & 08 & 03 & - & - \\
\hline 17. & Amphipleura sp. & 01 & - & - & - \\
\hline 18. & Mastigloia sp. & 05 & 03 & - & - \\
\hline
\end{tabular}


Int.J.Curr.Microbiol.App.Sci (2016) 5(8): 402-413

Table.3 Total number of isolates and genus found in the study area

\begin{tabular}{|c|c|c|c|}
\hline \multirow{2}{*}{ S.No } & Study period & \multicolumn{2}{c|}{ Bacillariophyceae (Diatoms) } \\
\cline { 3 - 4 } & & Isolates & Genus \\
\hline 1 & July- August, 2011 & 190 & 18 \\
\hline 2 & July- August, 2012 & 159 & 17 \\
\hline 3 & December, 2011 - February, 2012 & 95 & 12 \\
\hline 4 & December, 2012- February, 2013 & 87 & 08 \\
\hline 5 & Total no of Isolates & 351 & 18 \\
\hline
\end{tabular}

Plate-1

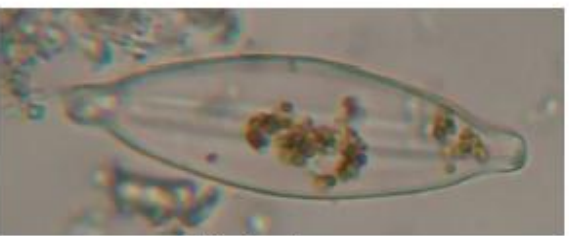

Navicula sp.

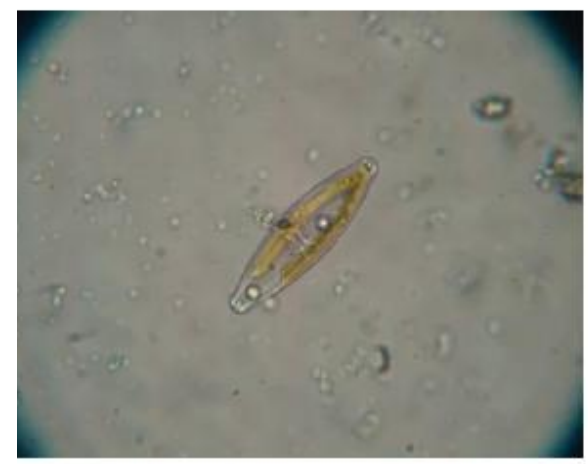

Staurneis sp.

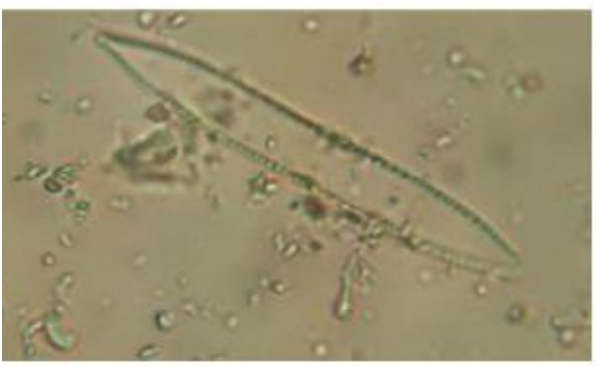

Nitzchia sp.

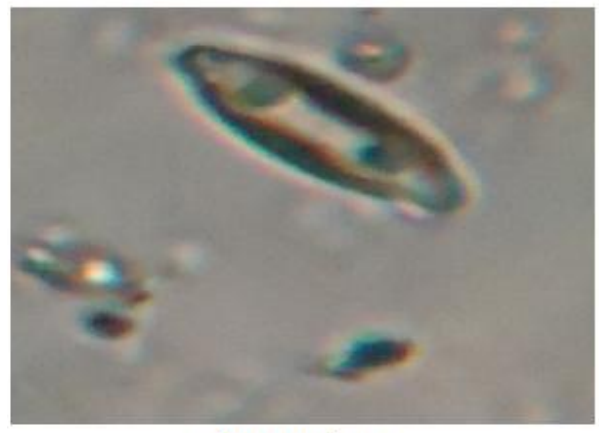

Staurneis sp.

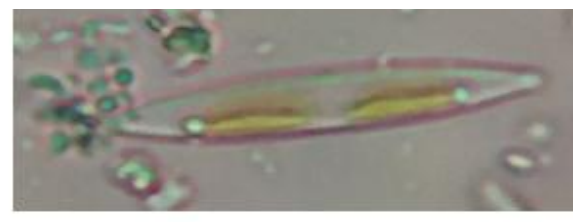

Achanthes sp.

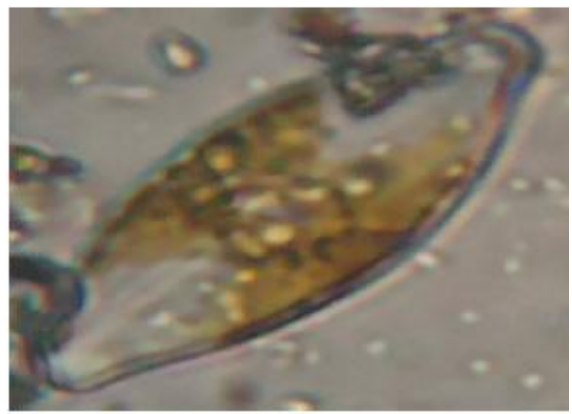

Navicula sp.

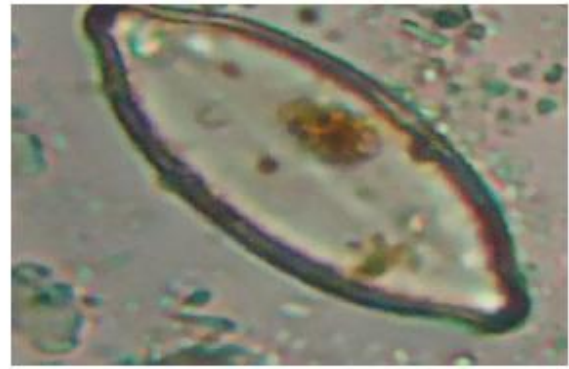

Mastogloia sp.

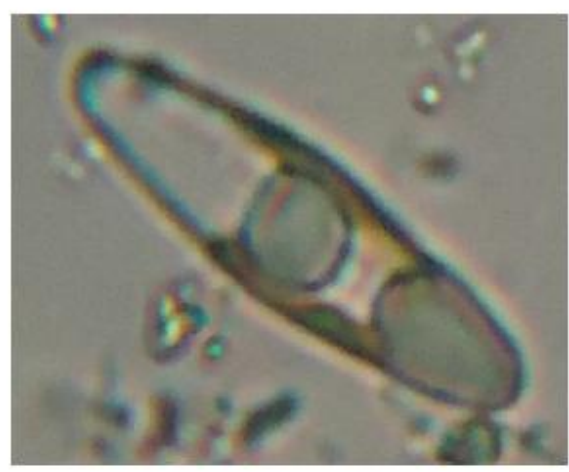

Nevicula sp. 


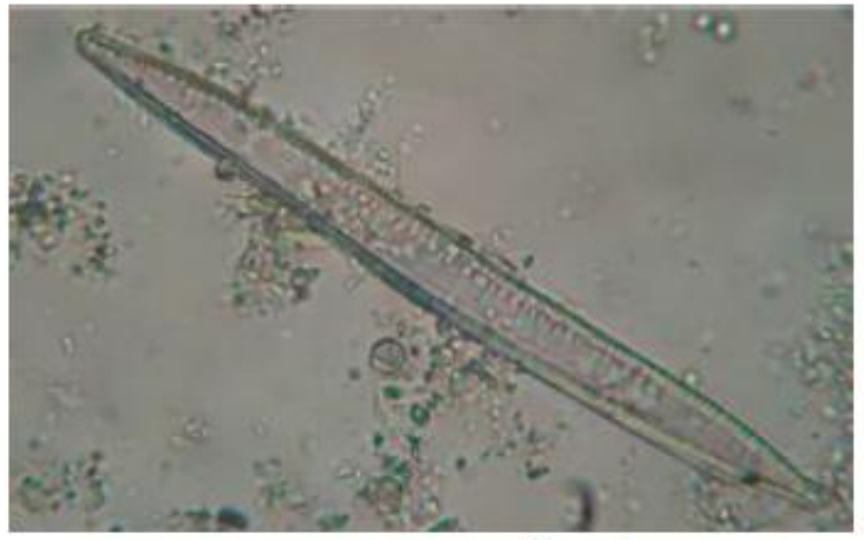

Synedra sp.

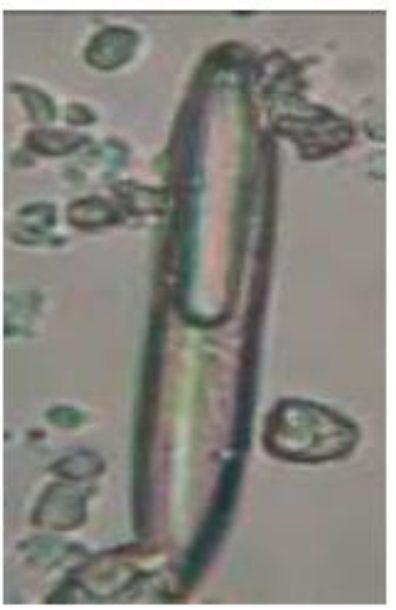

Nitzchia sp.

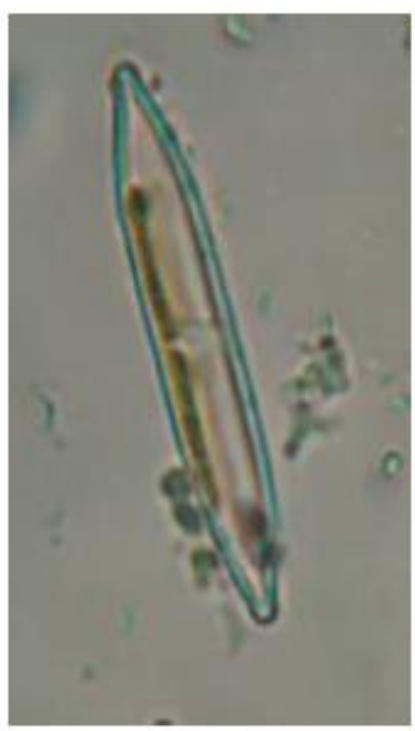

Nevicula sp.

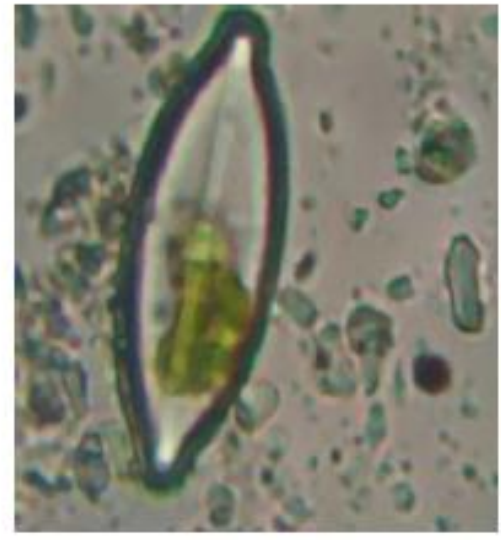

Mastogloia sp.

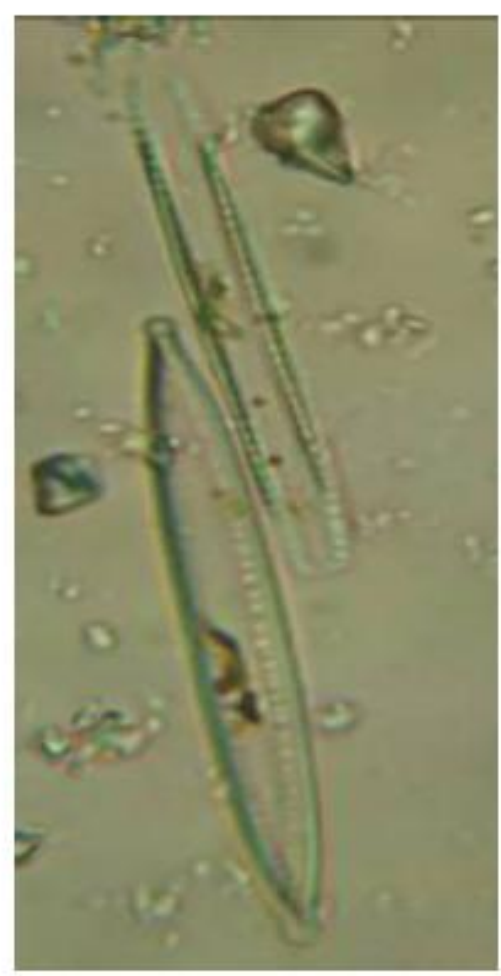

Synedra sp.

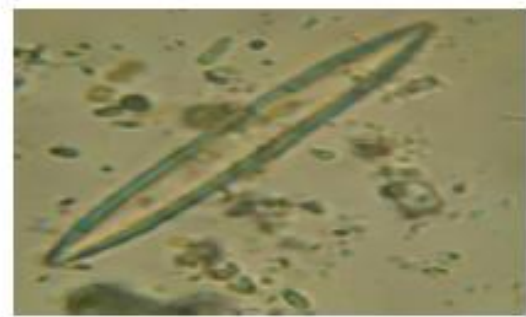

Synedra sp. 


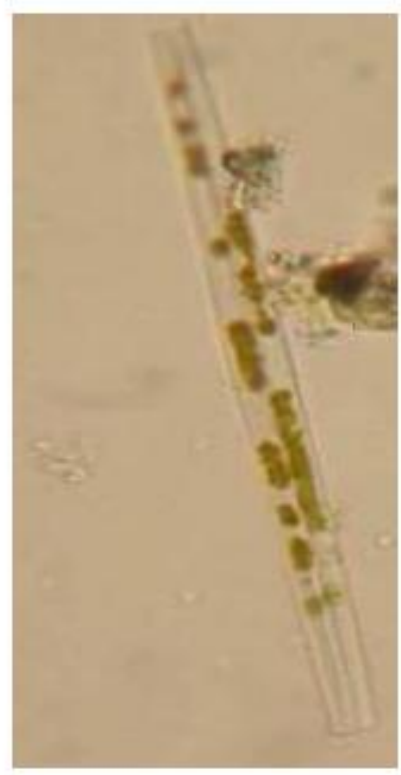

Synedra tabulate

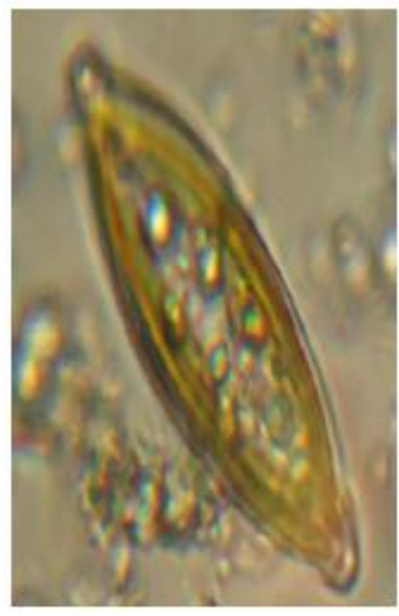

Nevicula sp.

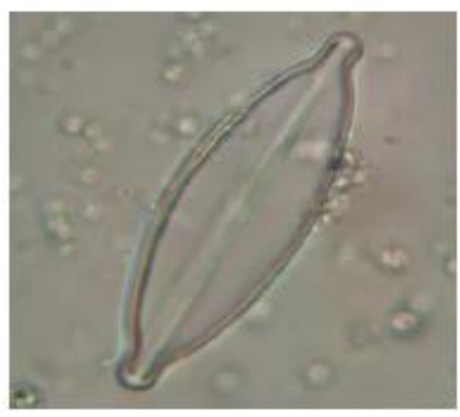

Navicula cuspidate

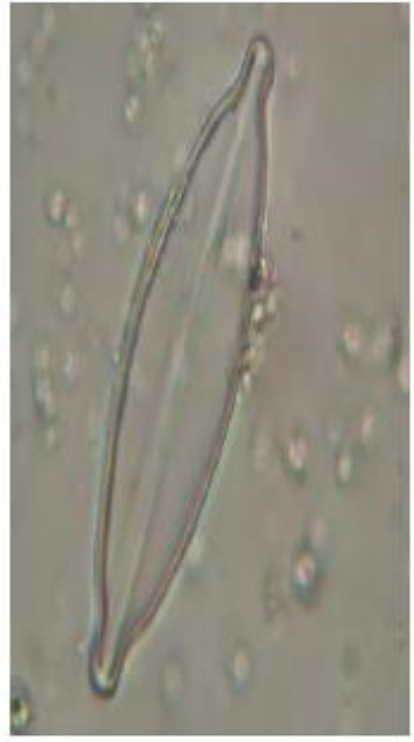

Nevicula $s p$.

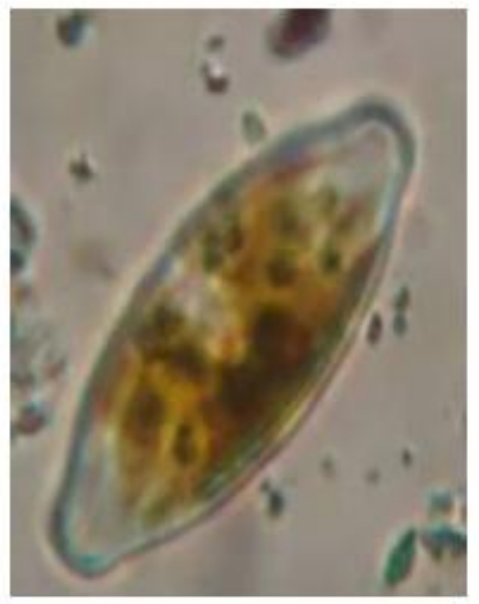

Coconeis sp.

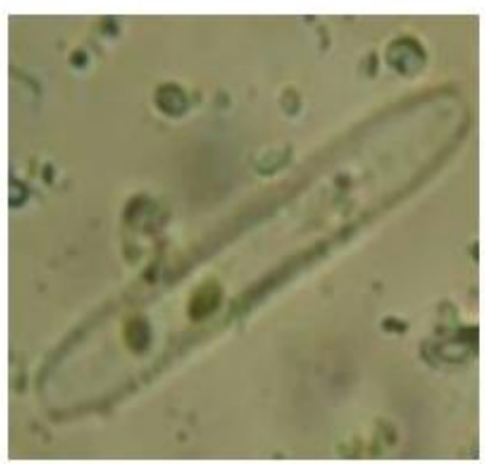

Neidium sp. 


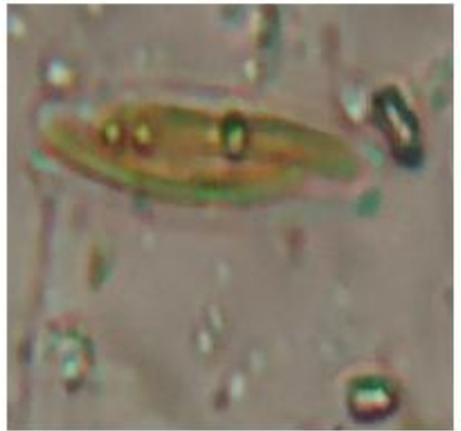

Frustulia sp.

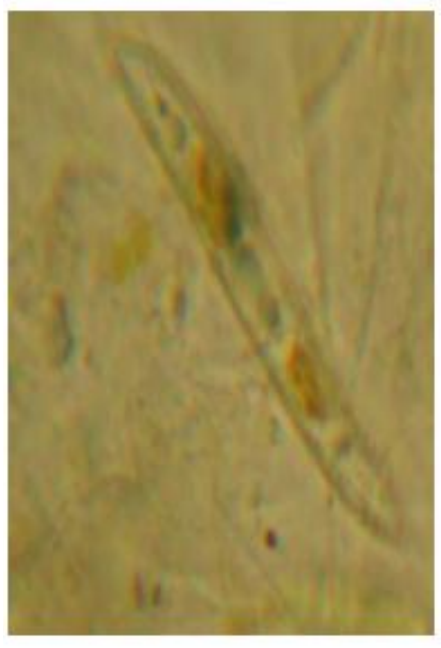

Gyrosigma sp.

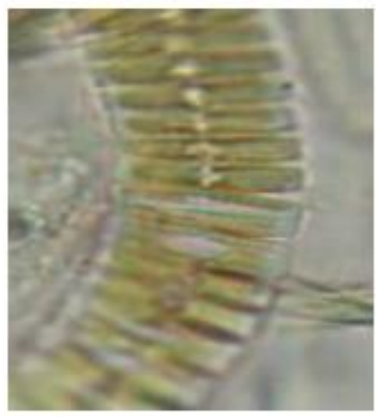

Fragillaria sp.

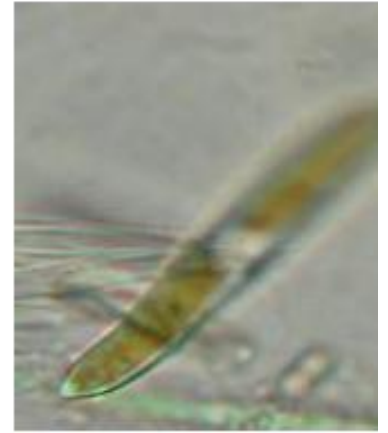

Gyrosigma sp.

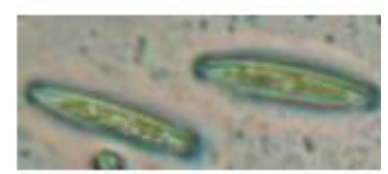

Navicula sp.

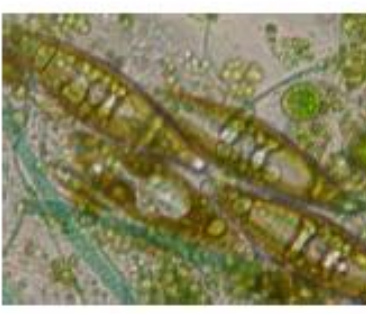

Navicula sp.

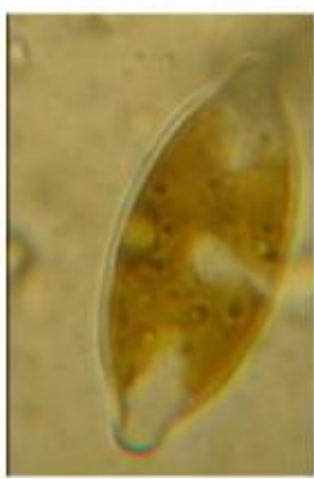

Mastigoloia sp.

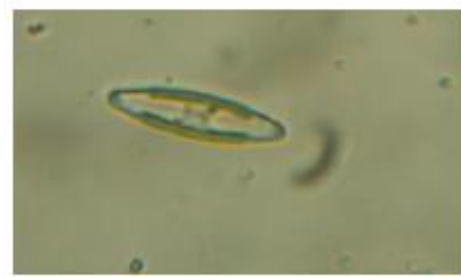

Calonies sp. 
The temperature and nature of the climate conditions are the reason for the difference between the ratios of diatom. In rice fields, temperature, light intensity and oxygen concentration are the key factors that control the distribution and abundance of various zooplankton (Payne, 1986).

In conclusion, biodiversity has great importance for human survival and ecosystem function and stability. Diatoms are enormously successful organisms as judged by their adaptability, distribution, biomass and relative antiquity. They account for up to $25 \%$ of the total oxygen production on earth. Their diversity is truly astonishing and the number of species may run to hundreds of thousands. More number of diatoms should be identified and to protect the magnificent biodiversity of our planet. We must create economic policies in order to maintain the earth's biodiversity and take appropriate measures to protect habitats and species.

\section{Acknowledgement}

I would like to thank the management of Muthayammal College of Arts \& Science, Rasiuram for providing necessary facilities required for this research work and I extend my thanks to Dr. N. Thajuddin, Associate Professor, Division of Microbial Biodiversity and Bioenergy, Department of Microbiology, Bharathidasan University, Trichirappalli and his research scholar who have lent a helping hand in identification of Diatoms.

\section{References}

Benson, H.J. 1998. Microbiological applications. $7^{\mathrm{TH}}$ edition. Laboratory manual in General Microbiology. WCB McGraw-Hill companies Inc USA 28-36.

Bhardwaj, K.B. and Tiwari, S.C. 2010.
Cyanobacterial diversity of two hyperthermal springs, Ringigad and soldhar in Tapoban geothermal field, Uttrakhand Himalaya. Curr. Sci., 99(11): 1513-1515.

Bhattacharya, P., Avir Kr. Choudry and Pal, R. 2011. Fresh water diatoms from Kolkata with special references to their taxonomy. Indian Hydrobiol., 13(2): $98-112$.

Birks, H.J.B., Line, J.M., Juggins, S., Stevenson, A.C. and Ter Braak, C.J.F. 1990. Diatoms and $\mathrm{pH}$ reconstruction. Philosophical Transactions of the Royal Soc. London, 327: 263-278.

Bongale, U.D. 1985. Systematic account of Diatoms from the cultivated soils of Karnataka state, India. Phykos, 24: 18 -26 .

Cooper, S.R. and Brush, G.S. 1991. Longterm history of Chesapeake Bay anoxia. Sci., 254: 992-996.

Cooper, S.R. and Brush, G.S. 1993. A 2,500-year history of anoxia and eutrophication in Chesapeake Bay. Estuaries, 16: 617-626.

Cramer, J. 1984. Algae; of the Indian subcontinent a collection of papers. Publication at Germany, 1-389.

Dean, W.E., Bradbury, J.P., Anderson, R.Y. and Barnowsky, C.W. 1984. The variability of Holocene climate change: Evidence from varied lake sediments. Sci., 226: 1191-1194.

Desikachary, T.V. 1959. Cyanophyta. I C A R New Delhi, 686.

Fritz, S.C. 1990. Twentieth-century salinity and water-level fluctuations in Devils Lake, North Dakota: Test of a diatom transfer function. Oceanography, 35: 1771-1781.

Fritz, S.C., Kingston, J.C. and Engstrom, D.R. 1993. Quantitative trophic reconstruction from sedimentary diatom assemblages: a cautionary tale. Freshwater Biol., 30: 1-23. 
Fujita, Y. and Nakahara, H. 2006. Variations in the micro algal structure in paddy soil in Osaka, Japan: Comparison between surface and subsurface soils. Limnol., 7: 83-91.

Fujita, Y. and Ohtsuka, T. 2005. Diatoms from paddy fields in northern Laos. Diatom, 21: 71 - 89.

Gandhi, H.P. 1956. Contribution to the knowledge of fresh water diatom of Dharwar. J. Ind. Bot. Soc, 35: 194209.

Gandhi, H.P. 1959. Fresh water diatoms from sagar in Mysore state. J. Ind. Bot. Soc., 38: $305-331$.

Gandhi, H.P. 1967. Notes on the Diatomaceae from Ahmedabad and its environs. VI. On some diatoms from fountain reservoir of seth Sarabhai's garden. Hydrobiologia, 30(2): 248 272.

Garg, A. and Bhaskar, P.V. 2000. Fluxes of Diatom in Dona paula Bay, West coast of India. J.Plankton. Res., 22(11): $2125-2136$.

Gopalakrishnan, P. 1972. Studies on marine planktonic diatoms off port okha in the Gulf of Kutch. Phykos, 12: $37-49$.

Gore, A.B. and Sanap, R.R. 2009. Phytoplankton diversity in Visapur Lake, Tal Shrigonda Dist. Ahmednagar (M.S). Proceedings of the International Conference on Algal Biomass, Resources and Utilization, 168-173.

Graham, L.G. and Wilcox, L.W. 2000. Algae, upper saddle river, NJ. Prentice Hall.

Griffith, R.E. 1961. Plankton of the Chesapeake Bay, An illustrated guide to the genera.University of Maryland Natural Resources Institute, 172. 1-79.

Hamed, A.F. 2008. Biodiversity and distribution of Blue-Green Algae/Cyanobactria and Diatoms in some of the Egyptian water Habitats in
Relation to conductivity. Australian J. Basic and Appl. Sci., 2(1): 1-21.

Jena, M., S.K. Ratha and Adhikary, S.P. 2006. Diatoms (Bacillariophyceae) from Orissa state and Neighbouring Regions, India. Algae, 21(4): 377-392.

Jensen, N.G. 1985. The Pennate diatoms. A translation of Hustedt's 'Die kieselalgen, 2. Teil' Koeltz Scientific books, Koenigstein. 918.

Kannan, L. and Vasantha, K. 1992. Microphytoplankton of the Pitchavaram mangals, Southeast coast of India : species composition and population density. Hydrobiologia, 247(1-3): 77 - 86.

Kikuchi, E., Furusaka, C. and Kurihara, Y. 1975. Survey of the fauna and flora in the water and soil of paddy fields. Rep Inst. Agric. Res. Tohoku Univ., 26: 2535.

Krammer, K., Lang-Bertalot, H. 1986. Bacillariophyciae. Naviculaceae. Gustav. Fisher verlag. Stuttgart. New York. 876.

Leelahakriengkrai, P. and Peerpornpisal, Y. 2008. Diversity of benthic diatoms in major rivers in Thailand and establishment of water quality indices. Research and thesis. $12^{\text {th }}$ BRT Annual Conference, Suraj Thani.

Marshall, H.G. 1984. Seasonal phytoplankton composition and concentrations in the lower Chesapeake Bay and vicinity. Old Dominion University Research Foundation Grant DACW65-81-C0051.

Marshall, H.G. 1986. Diatom associations of the northeastern Continental Shelf and Slope Waters of the United States, in Richard, M., (ed.), Proceedings of the $18^{\text {th }}$ International Diatom Symposium: Koenigstein, Koeltz Scientific Books, 539-548.

Morse, D.C. 1947. Some observations on 
seasonal variations in plankton population. Patuxent River, Maryland 1943-1945. Chesapeake Biological $L a b, 65: 1-31$.

Mulford, R.A. 1962. Diatoms from Virginia tidal waters, 1960 and 1961. Virginia Institute of Marine Sci., 30: 1-33.

Nair, P.V.R. 1959. The marine planktonic diatoms of the Trivandrum coast. Bull. Inst. Univ. Kerala. Ser. C7: 165.

Nair, P.V.R. 1960. On two diatoms from the inshore waters of palk Bay. J. mar. biol. Ass. India, 2: 196 - 198.

Norton, T.A., Melkonian, M. and Anderson, R.A. 1996. Algal biodiversity. Phycologia, 35: 353-363.

Ohtsuka, T. and Fujita, Y. 2001. The diatom flora and its seasonal changes in a paddy field in Central Japan. Nova Hedwigia, 73: 97-128.

Patten, B.C., Mulford, R.A. and Warinner, J.E. 1963. An annual phytoplankton cycle in the lower Chesapeake Bay. Chesapeake Sci., 4: 1-20.

Payne, A.I. 1986. The ecology of tropical lakes and rivers. John Wiley and Sons New York.

Prasad, B.N. and Jaitly, Y.C. 1985. Diatom flora of a high altitude spring in Ladakh. Phykos, 24: 132 -139.

Ramamoorthy, S. 1965. Studies on the plankton of North kanara coast in relation to the pelagic fishery. J. mar. biol. Ass. India, 7: 127- 149.

Sarode, P.T. and Kamat, N.D. 1979. Diatoms of Marathwada, Maharashtra
-I. Phykos, $18: 25-32$.

Sheehan, J., Dunahay, T., Benemann, J. and Rossler, P. 1998. A look back at the U.S Department of Energy's Aquatic Species program: Biodiesel from Algae. National renewable energy laboratory Golden $\mathrm{CO}$ (US) NREL/TP-580-24190 2-3.

Somashekar, R.K. 1983. Algal flora of river Cauvery, Karnataka.II. Diatoms. Phykos, 22 : $81-85$.

Somashekar, R.K. 1984. Contribution of the algal flora of river Kaplia, Karnataka II. Diatoms. Phykos, 23 : 125 -129.

Stoermer, E.F. \& Smol, J.P. (eds) 1999. The diatoms: applications for the environmental and earth sciences. Cambridge University Press, Cambridge.

Taire, M. and Hogestu, K. 1987. Species composition of phyco and zoo plankton communities in fertilized and non-fertilized paddy fields. JPN .J. Limnol., 48: 77-83.

Venkatraman, G. 1939. A systematic account of some South Indian Diatoms. Proc. Indian. Acad. Sci., 10: $293-365$.

Vidyavati. 2012. Algal biodiversity through ages and prospects. Indian hydrobiol., 14(2): 95-98.

Wolfe, J.J., Cunningham, B., Wilkerson, N.F. and Barnes, J.T. 1926. An Investigation of the Microplankton of the Chesapeake Bay. J. Elisha Mitchell Scientific Soc., 42: 25-54.

\section{How to cite this article:}

Nashima, K., and Palanisamy, A. 2016. Prevalence and Distribution of Diatoms in the Paddy Fields of Rasipuram Area, Namakkal Dt, Tamilnadu, India. Int.J.Curr.Microbiol.App.Sci. 5(8): 402-413. doi: http://dx.doi.org/10.20546/ijcmas.2016.508.043 